\title{
Shakuntala: As Authored by Kalidas and Painted by Raja Ravi Varma
}

\author{
Anasuya Adhikari ${ }^{1}$, Birbal Saha ${ }^{2}$ \\ ${ }^{1}$ Research Scholar, ${ }^{2}$ Professor, \\ Department of Education, Sidho-Kanho-Birsha University, Purulia, West Bengal, India \\ Corresponding Author: Birbal Saha
}

\begin{abstract}
Mythology has always been an appealing area which has been engrossing readers and listeners since ages. Mythology plays distinctive roles and employs its sacred narratives, art and rituals to keep the values and morals of the society intact. This system of writing texts on mythology was common to the entire subcontinent and produced its own literature written in Sanskrit. One such magnum opus is Abhijnanashakuntalam authored by the great Sanskrit maestro, Kalidas. It is also important to note that mythology in the form of texts was accessible to a very limited class of people which included the elites, literates, scholars etc, and consequently a large section of the society remained unaware of these episodes and virtues. It is where, Raja Ravi Varma, 'Father of Modern Indian Art' is credited to bring these episodes in the form of both painting and printing to the commoners. This not only attracted a huge number of people towards mythology, Hindu culture and tradition but also urged to preserve values. The present paper is an attempt to study the contributions of the two maestros, Kalidas- as the author of Abhijnanashakuntalam and Raja Ravi Varma-as the painter of the Shakuntala Series, comparative studies of how both the maestros perceived the character of Shakuntala, portrayal of 'beauty', and how the play, painting and printing was appreciated, responses gathered and inspirations shared.
\end{abstract}

Keywords: Kalidas, Raja Ravi Varma, Shakuntala, Mythology and Painting, Oleographs

\section{INTRODUCTION}

Mythology is often described in the academic studies as, "deeply valued stories that explain a society's existence and world order: those narratives of a society's creation, the society's origins and foundations, their god(s), their original heroes, mankind's connection to the "divine", and their narratives of eschatology". The same concept becomes a very common outline for the numerous, basic and sacred stories which bear the similar themes. "Myth constructs a worldview for people. It serves as a looking glass through which life comes to order" (Pattanaik, 2003, p.34) To sum up in an academic sense, myth simply refers to traditional stories. However, the area is yet under contradictions, since many scholars regiment the term ' $m y t h$ ' at par with 'sacred stories'. "Believers make a narrative sacred and endow it with mythic power. In the secular realm myth may still be fascinating when shorn of its sacred splendour. It will entertain but not empower. It may move a person through his or her lifetime but never bind people over generations. Without faith these vital elements of culture are reduced to amusing tales, impressive art, and curious customs" (Pattanaik, 2003, p.11).

India is the home and harbours Hinduism. Hinduism places substantial emphasis on the worship of icons. Purānas speak of a set of Hindu religious texts, dating back to the 4th century, emphasising divine power embraced within an object, which might be awakened through worship. 
The biggest and bulk producer of printed images in modernity, makes India remarkable. Images are one of the most powerful way of communication. This might be considered true since they are accessible to both the sections of the society- the illiterate and the educated people. Thereafter this accessibility is "the democratic value intrinsically embedded in images." The availability of images, gives them a strong potential to turn themselves into powerful weapons to be used for religion, society and the formation of political ideology, which can be understood by people from all sections of the society. "The stories and myths of India are a rich and varied tapestry unlike any other in the world. Step inside this world and be amazed, thrilled, and terrified, just as millions of others around the world have been for thousands of years" (Ramen, 2008).

\section{THE PLAY AS AUTHORED BY KALIDAS}

Kālidāsa $\left(4^{\text {th }}-5^{\text {th }}\right.$ century CE, exact dates unknown) is credited to be the Father of Indian Literature, a Sanskritauthor and considered to be ancient India's greatest playwright. His penned themes primarily dominate the episodes and incidents from the Vedas, the Purānas, the Rammāyana and the Mahābhārata. There are no such proper evidences found about his place of birth or his life and hence, speculations engulfed views conclude that Kâlidāsa might be a native from near the Himalayas (Ujjain, and Kalinga). This hypothesis of the scholars is based on Kalidas' description of the Himalayas, written so specifically and beautifully in his Kumārasambhava. The renowned philosopher, Humboldt pronounces, "Kalidas, the celebrated author of Shakuntala, is a masterly describer of the influence which Nature exercises upon the minds of lovers. Tenderness in the expression of feelings and richness of creative fancy have assigned to him his lofty place among the poets of all nations." (Kale, 1969. p.14)
Abhijnanashakuntalam is also known as Shakuntala, The Recognition of Shakuntala, The Sign of Shakuntala, is a Sanskrit play belonging to the class of Rupakas and is penned by the ancient Indian poet Kalidas. It dramatizes the story of Shakuntala as narrated in the epic Mahābhārata. It is regarded as Kalidas' best works. The story of Shakuntala also can be traced in the Padmapurana, Svargakhanda, but the one present in the Mahabharata finds a greater importance. The story of Shakuntala with a similar plot also appear in the Buddhist Jātaka tales. In the Mahabharata, the story of Shakuntala bears to be a precursor to the Pandava-Kaurava lineages. The story narrates, King Dușyanta and Shakuntala meeting in the forest and getting estranged from each other and ultimately reunited with each other. It is their son Bharata, who is credited to have laid the foundation of the Kaurav-Pandava dynasty. "An expression of myth becomes sacred when it is of anonymous origin, a revelation or a communication from a nonhuman source" (Pattanaik, 2003, p.15.) The plot is a blend of perfect naturalness of the dramatic incidents. The dramatic incidents soberly culminate upwards in the advancement of the plot. All these tend to give approval to the play as an impeccable creation. The classic Abhijnanashakuntalam, is therefore the intensification of the dramatic and poetic skills of Kalidas.

King Dușyanta of the Puru Dynasty, marries Shakuntala (originally the daughter of Vishwamitra and Menaka) in the forest hermitage, living with her adopted father Kanva. Later Dusyanta rebuffs the acceptance of Shakuntala as the lawful wife, pregnant with his child. Kalidas deciphers this alleviating the crude narrative of rejection and betrayal, taken from the epic Mahabharata, by moulding components of the supernatural fable, reasoning the curse of forgetfulness spelled by Durvasa. Shakuntala was lost in the thoughts of Dusyanta and had slipped to serve when the sage came to the ashram premises seeking for food. Shakuntala was humiliated and 
rejected by her amnesiac husband and also by the priests, who accompanied her from Kanva's hermitage. It is from here that Shakuntala is abducted by Mishrakeshi, who was the apsara-friend of Menaka.

The final act of the play concludes, that Shakuntala is taken reserved to Aditi and Maricha's hermitage. This hermitage was located somewhere transcending the world of mortals. Now what did this mean? We might decipher the meaning here, that Shakuntala leaves her mortal body and only her soul is reserved to the spiritual world. It might also suggest that Shakuntala is competent to enter the spiritual world since she is an immortal. The immortal world makes Dusyanta finally reconcile and recognise Shakuntala and their son Bharata. The husbandly recognition gives the play its present name, Abhijnanashakuntalam, the recognition of Shakuntala. Kale pens down the essentials of the qualities of the heroine of a play, and Shakuntala rightly fits into it: "The Nayika or the Heroine, who must be possessed of qualities similar to those of the Hero" (Kale, 1969, p.5). But it is a matter of thought, that why was this 'recognition' special? We are bound to hover over this matter, if this is the same mould of 'recognition' which has been ever entrusted upon every conscientious wife throughout the lengthy and dominant history of Indian patriarchy? Hovering over Kalidas' real recognition, it is obligatory to look into the one which the author wanted to draw our attention to, even if he worked within the regimentation of Brahminical conventions. These conventions might turn Sanskrit drama converting it into an "artificial genre of sacerdotal piety and courtly flattery" (Betageri, 2018).

\section{TECHNICAL REMARKS AND THE DEATH OF THE AUTHOR}

Sanskrit love-dramas have possessed remarkable features. These features are well exemplified in Shakuntala, which is possibly the mightiest representative of its class. They are- temporary union, separation and re-union. On perceiving the complete play, it turns easy to comprehend that, the plot engrossed in the acts of Shakuntala are constructed in the ascending order, which would further facilitate temporary union. The romantic expedition, which is common in any other play, puts the hero and the heroine to confront each other's path; leading to the invitation of the hermits for Dusyanta to keep guard and protect the hermitage; and the avid bilateral love in its consummation. These three can be considered the possible stages arranged into ascending order of the three acts. After the steady rise of the events, the descent begins. "It is a dictum of Sanskrit critics that there is no charm in love unless it is sweetened by separation. Acts 4, 5, 6 of the Shakuntala delineate this downward progress of separation" (Kale, 1969, p.50).

In this play, Kalidas accepts both his own death as a poet and the death of his intensities. This he does by the breathtaking conventions of life enrolled into literature. The author pens the final scene of the last act very differently, very much similar to a man who is about to die. It also shares a feeling of some vital spiritual satisfactoriness, after the final line of action is concluded; he embraces it "over his poetself like a shroud, exhausted and accepting of all powerfulness of Fate". Shakuntala is such a play (very much unlike Kumarsambhava, where the poet takes a new birth as the Creator), in which the poet dies leaving the shell of the world behind, and thereafter, this play becomes "the mandate-by-convention happy-ending is a tragedy.' (Betageri, 2018)

\section{THE STORY NARRATED AS PAINTING BY RAJA RAVI VARMA: LOVE FOR MYTHOLOGY}

Raja Ravi Varma (1884-1906), an aristocrat of Travancore, can be credited for being the first of 'the new Indian artists of British India' and known as 'Father of Modern Art in India', who brought new connotations significant to the ipseity of an artist, specifically, that of an 'Indian artist'. Raja Ravi Varma was the first Indian 
painter to bring the European form of painting to the country, blending it with Indian flavour, illustrating Hindu mythologies. The most successful individual painter of the country, was subjected to extreme hostility, see-sawing his image between the two extremes.

The Bengal School of Painters criticised Raja Ravi Varma, since the former believed in nationalism and were obsessed with the Indianness of form and spirit. Hence, Ravi Varma's style was criticised as being imitative, European and 'blasphemous'. "The disavowals of Ravi Varma became an integral part of the movement for an 'Indian style' of painting in the first decades of this century. But an appreciation of this first 'Indian artist' and his kind of mythological paintings was as much the immediate response to his work. At the peak of his fame, his 'pauranic' pictures were the rage of rajas and notables, the usual clientele for religious pictures, and the educated middle class, even of Bengal" (Thakurta, 1986, p.166). The hybrid styles produced by Raja Ravi Verma, hence have "been classified under the broad umbrella term of 'Company' or Anglo-Indian painting." (Thakurta, 1986, p.167)

\section{FEMININITY IN HIS PAINTINGS}

Raja Ravi Varma's success revolved crucially around certain factors. Ravi Varma dealt with the two hallmarks of Westernised painting in $19^{\text {th }}$ Century India. He dealt skilfully in handling the new medium of oil and at the same time the advanced style of photo-illusionism. He had moved into such an innovative style of painting and illustration, which was considered far 'better' by both his mentors and patrons. It was also vital how these techniques were employed and skills were diligently used. His portraits were life-size, adorning all the refinement of the Western Academic techniques of oil painting. It is interesting to point here, how Ravi Varma dealt with painting Indian women, which later became his focal point. Ravi Varma's notions and techniques on symbolism, conventions of romanticism and sensuality developed from the European Academics of the time and turn out to be paintings to become pathbreakers.

The real breakthrough however, ushered in a completely new kind of illustrative religious painting, which was devotedly based on classical literature and Indian mythology. It was these paintings which catapulted the high-soaring fame and career of the artist. Thereafter, these new illustrations and paintings attracted patronage and soon gathered popularity, which commissioned the future portraits studies. The artist' 'pauranic' pictures (paintings and illustrations) also appealed largely to educated and refined taste. "The most important symbolism in Hinduism is that of man and woman. In most narratives man represents spiritual reality; woman represents material reality. He stands for otherworldly pursuits; she stands for worldly passions. Worldliness is impossible without the presence of women; monasticism demands the absence of women. Man is the soul. Woman is the flesh. $\mathrm{He}$ is the cause. She is the manifestation. He is the self, pure awareness, and the true identity of our being" (Pattanaik, 2003, p.26-27). Raja Ravi Varma seemed to believe this notion.

The themes of the images were ostensibly Indian. More interestingly, these set of paintings matched up with the rising familiarity of the middle class. The elite and literates were accustomed with the rich history of India and allegory paintings of the artists of the European Academy, which were circulated in the country reproducing prints and magazine. The realism portrayed technically in these paintings, and the romantic values in the portrayal of scenes along with the dramatization of the characters, "found their best Indian representation in the works of Ravi Varma."

Ravi Varma conceptualised and idealised the feminine figure, in the later studies of human figure and mythological paintings. Ravi Verma used the same 
'guileful mannerisms' used in the Academy paintings. At the same time, he provided Indianness, with the use of cloth and ornamented which is a common feature elaborated in the Indian costumes. All along with these he conceived the narrative paintings as Damayanti, Shakuntala and Draupadi. These paintings became the new faces and much-admired 'devis' of Hindu legend. Interestingly enough, even in this place, Ravi Verma used European illustrations as reference points. "These women in Ravi Varma's paintings became stereotyped models of femininity, in their sensual appearances, in their evocative facial expressions and in the leisurely mood of their actions" (Thakurta, 1986, p.179).

\section{THE SHAKUNTALA SERIES - THE BAZAAR PAINTINGS}

The Bazaar Painting school was influenced by 'the European encounter in India.' These paintings were unlike the Company paintings which was a mixture of the European techniques combining Indian themes. The Bazaar School was not influenced by the Indians but had strongly taken the Roman and Greek influence. The Gaekwar of Baroda (Sayaji Rao) invited Raja Ravi Varma and commissioned 14 mythological paintings, from 1888-1890, to adorn the New Hall at the Lakshmi Vilas Palace. The motif behind this was to keep the splendour of India's heritage alive. To fulfil portrait commissions and also to continue with this project, Raja Ravi Varma and his brother, C. Raja Raja Varma, toured the whole of India, to learn drawing sketches of clothes, draperies, local adornments, as well as to paint weapons. The main motive behind this to learn to paint models for the proposed epic paintings. Both the brothers also read a number of Sanskrit texts and epics which would clear their motifs and at the same time derive a clear picture of the plot to enhance their characters. For the paintings Ravi Varma choose the drapery sari for his epic heroines. This brought in the pan-
Indian acceptance of sari which was among the formal dresses for women in India.

\section{Shakuntala Patralekhan (Shakuntala's Love Letter to Dushyanta)}

This was the first of his classical painting, was exhibited in Madras in 1876, becoming a path-breaker in its own ways. Immediately this painting was bought by Lord Buckingham, Governor of Madras. Sir Monier Williams, reproduced this painting in the frontispiece of the later version of a translation of Shakuntala in $1855 . \quad$ Ravi Verma redefined the taste of mythology with his subtle combination of his portrayal of the characters, use of apt colours and very skilfully keeps the background less clumsy and natural. Shakuntala is seen here sitting pensively along with her friend, and writing a letter to Dyshyant in a leaf. The treatment of the background is absolutely picturesque, simple and clear. The success of this painting was vital, since it opened 'flood gates for huge flow of similar mythological paintings by the artist throughout the rest of the career.' Ravi Verma studied women through life-studies and portrayed them into romantic and rarefied gestures.

There is no extra use of any item found in the painting, which Kalidas might also have wanted to show in his text:

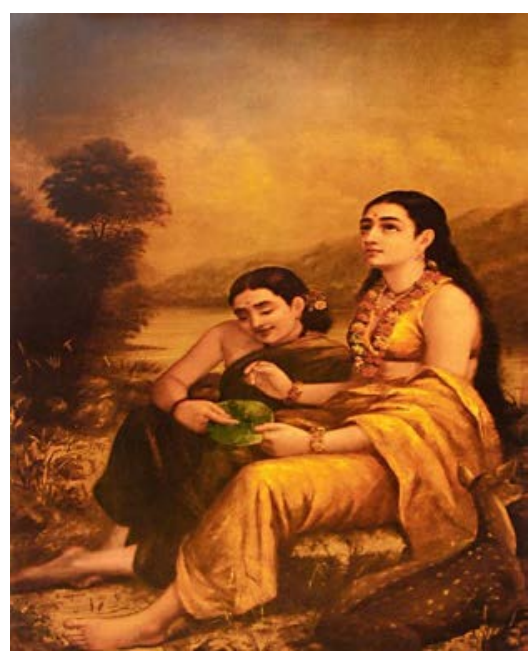

"Priyanvada: Friend, let a love-letter be written to him. Having concealed it in flowers, I will deliver it into his hands, under the pretext of flowers (removed from 
the image of a diety and given as a mark of favour.

Anasuya: I approve of this delicate plan; but what does Shakuntala say?

Shakuntala: What! Can your arrangements be ever questioned by me?

Priyanvada: Then think about some pretty composition, introduced by a reference to yourself.

Shakuntala: I shall think, friend, but then, my heart trembles, afraid of repulse.)" (Act 3 Scene 2, Translation)

\section{* Shakuntala and Her Friends (1898)}

This is a $110 \mathrm{~cm}(43 \mathrm{in}) \times 181 \mathrm{~cm}$ (71 in) painting, which is presently housed in the Sree Chitra Art Gallery, Tiruvantapuram, India, features the artistic genius. Ravi Verma being a devout lover of mythological figures, might have read the works of the Sanskrit maestro, Kalidas to absorb the theme and story of the life of Shakuntala. Ravi Verma's painting is a pure delight of the Rasas. "Rasa is the lasting impression of feeling produced to his overwhelming delight in a man of poetic susceptibility by the proper action of the Vibhavas and the Anubhavas, as well as the Sattvika Bhavas and the Vyabhicharibhavas" (Kale, 1969. p.6).

The painting depicts Shakuntala and her two friends, Anasuya and Priyanvada. Shakuntala is shown here "pretending to remove a thorn from her foot, while actually looking for her husband, Dusyanta, while her friends call her bluff." Asimilar process engulfing the transmutation and transformation of values and morals related to the painting images occurs in the artist's painting of the other paintings in this series. Shakuntala's simple saffron garments, adorned with beautifully painted flower ornaments, provides a testimony of her being a forest maiden, as conceived and written by Kalidas. "The painting of $a$ theme from 'Abhijnanashakuntalam' in 1876 runs parallel to changes in late nineteenth century Malayalam literature, the rise of a new literary unit of 'mahakavyas' and dramas on the model of
Sanskrit literature, and a new spurt of translations and adaptations of the Sanskrit classics" (Guhathakurta, p.182).

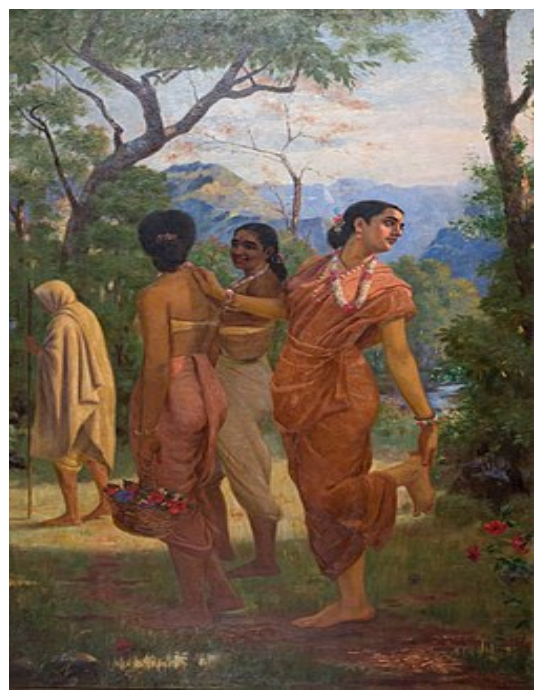

Quoting Kalidas’ Abhijnanashakuntalam, "Priyanvada- Anasuya, do you know why Shakuntala is looking so very attentively at Vanajyotsna?

Anasuya- No. I cannot conceive it; pray tell me.

Priyanvada- As Vanajyotsna has been united to a tree worthy of it, so may I, too, get a suitable husband! (This is what she is thinking about).

Shakuntala- Certainly this must be the desire of your own heart (Empties the jar of water)." (Act 1 Scene 2, Translation)

Ravi Verma's painting suggests more than what it expresses. They are a treat to the eyes. The expressions of the characters and most importantly the selection of the episodes are worth appreciation. Tapati Guha-Thakurta writes; "[T] his very gesture - the twist and turn of head and body - draws the viewer into the narrative, inviting one to place this scene within an imagined sequence of images and events. On its own, the painting stands like a frozen tableau (like a still from a moving film), plucked out of an on-running spectacle of episodes. These paintings also reflect the centrality of the "male gaze" in defining the feminine image. Though absent from the pictorial frame, the male lover forms a pivotal point of reference, his gaze transfixes Shakuntala, as also Damayanti, 
into "desired" images, casting them as lyrical and sensual ideals."

\section{The Shakuntala Series- In Printing: Oleographs}

On the advice of T. Madhava Rao, the then Dewan of Travancore, Ravi Varma proceeded with a lithographic printing, Raja Ravi Varma Press in Ghatkopar, Mumbai in 1894. This press was later shifted to Malavli near Lonavala in 1899. The oleographs (a unique method for making multi-colour prints) produced by the artist's press comprised mostly of Hindu gods and goddesses. They were depicted in scenes which were adapted mainly from the epicsMahabharata, the Ramayana and the Puranas. Ravi Varma's oleographs became very popular and even continued to be printed after the death of Ravi Varma in 1906. The Ravi Varma Press was the largest, unique and the most innovative press in India during that time. Ravi Varma's brother, Raja Raja Varma managed the press, but under their management the press was a commercial failure.

Ravi Varma's career is an admixture of various distinctive characteristics which laid in his new projects of success undertaken and publicity- the first being the prestigious network he entered into British fine art exhibitions which included its awards and the second was the innovative technology of reproduction of paintings (including engraving, lithography and oleography). "The novelty was the picture press set up by Ravi Varma in Bombay, for printing cheap and multiple colour reproductions of his mythological paintings, to capture an all-India clientele far beyond the exclusive world of his patrons. The career of this single artist therefore becomes a watershed in the history of modern Indian art." (Guhathakurta, 1986. p. 176)

It signifies the emergence of the individual artist and the growth of a characterised-classy Indian dimension in painting. All these was framed within a modernised stylistic context. It becomes more important to understand the point at which the developing indigenous genre of court painting which merged, integrating vividly into the more organised world of British art education. It provided new directions of professionalism and commercial success. "What is important for Indian Art History is that Ravi Verma, besides his thriving portraiture business and commissions for mythological themes, also began the industrial reproduction of his mythological pictures in his Ravi Verma Fine Arts Lithographic Press. With all these prints, he was able to address a wide and socially heterogeneous Hindu audience; he visualised their mythology in a pictorial code confined until then to the colonial and aristocratic echelons of the middle and upper classes."- (Introduction, C. Raja Raja Varma's diaries published as Raja Ravi Varma: Portrait of an Artist, p.2)

Ravi Varma focused highly on the pleasure of books. The boom in commercial publishing resulted in producing a wide variety of texts. These new texts intervened into the pre-print world consisting of oral performance, which produced new literary habits. However, they did not entirely replace them. The press was deeply in debt by 1899. In 1901, the press got sold to Fritz Schleicher, a printing technician from Germany.

The following Oleographs from the Shakuntala series were produced by the Ravi Varma Press:

A. Birth of Shakuntala (Vishwamitra and Menaka), printed at the Ravi Verma Press, c.1900

B. Vishwamitra and Menaka, Oleograph, c. 1905, from a painting by Ravi Verma from 1890

C. Vishwamitra and Menaka, printed at the Ravi Varma Press, c. 1905.

\section{RECEPTION OF THE PLAY, PAINTING AND FURTHER ADAPTATIONS}

Reception of the Text: Sir William Jones' Sacontalá or The Fatal Ring, a translation of Kālidās's play, was first published in 
Calcutta. This was followed by European republications in 1790, 1792 and 1796. Franco Alfano, an Italian, composed an opera named La leggenda di Shakùntala (The legend of Shakùntala) in 1921. The second version of Shakùntala was published in 1952. Bengali translations of the play were of the same name, penned by Iswar Chandra Vidyasagar in 1854 and Abanindranath Tagore in 1895. Even though the west was sincerely interested in the mythology and specifically in the play, Shakuntala, it was disapproved as a text to be taught in the school and colleges. Popular Indian literature was penned in the words of Charles Trevelyan, to be "marked with the greatest immorality and impurity". Indian students were predicted by colonial administrators to be insufficient in terms of moral and intellectual, and were not fit to read the Indian texts that were taught and praised in Britain. Hence followed its disapproval.

\section{Reception of Ravi Varma's Paintings and} Oleographs: Reception of Ravi Varma's paintings and oleographs were also not free from controversies. Though he was praised and supported by both British and Indians alike for his portraiture to religious works, eventually by the end of the 19th century, his popularity dwindled between the two extremes- between applauding his work as a new genre to denote his portrayal of the Hindu goddess as 'vulgar'. According to some, Ravi Varma was "convinced of the need to provide an alternate to the 'atrocious' and 'debased' varieties of cheap religious pictures that flooded the market, and thus improve popular taste. It is not certain whether or not his motives were explicit to this extent, Ravi Varma certainly went ahead to transform the "religious picture market once he began releasing paintings as prints available to the masses" (Guhathakurta, 1986).

Reception in Media: The early cinemas made in India were inspired by popular prints. The profuse beauties initiated in early cinema and calendars descended from Ravi Varma's heroines. Before films were considered as an art, they were used only as a recording device. It was only after Dadasaheb Phalke, (now hailed as the 'Father of Indian Cinema'), "became big in the art scene, just as Ravi Varma seemed to be fading into the background." Phalke went to Sir J. J. Art School in Bombay, as a photographer and gradually developed his interest in cinemas. While working at the Archaeological Society of India as a draftsman, he specialised in lithographs. It is only after this he worked for the Ravi Varma Press as a lithographic transfer artist. Phalke's experiments in cinema not made it something larger-than-life film industry that thrives in India today. It drew his own inspiration from the Ravi Varma approach.

\section{CONCLUSION}

Ravi Varma's 'pauranic' portrayals and the paintings of women he produced later, carried more predominant overtones of allegory and idealism. "But while the ideal and the emotion, and the religious, literary or moral allusions became all important in a painting, there was a noticeable erosion of technical finesse and aesthetic elegance. This steady debasement of standards, even more evident in the oleographs ran parallel, paradoxically, to the growing success and popularity of the artist" (Guhathakurta, 1986. p.191) It is really interesting to note that Ravi Varma's paintings drew clear inspiration from the Hindu mythological episodes, but it is also clear that Kalidas' texts posed a vivid dominance in the paintings. The motive behind mythology was to develop moral and virtues, which initially the written texts communicated. But the written texts soon became regimented to the educated, scholars and elite class. Thereafter, Ravi Varma's attempt in painting and printing episodes from Hindu mythological texts, helped in communicating the stories to the mass, irrespective of their class and literacy. People could now easily visualise the characters and the plot. Thus, both the maestros, Kalidas (literary) and Raja Ravi Varma (painter) provided a wide- and far- 
reaching impact on the society which is lasting and will last and inspire the generations to come.

\section{Acknowledgement: None}

\section{Conflict of Interest: None}

\section{Source of Funding: None}

\section{REFERENCES}

1. Arunima, G. (2003). Face value: Ravi Varma's portraiture and the project of colonial modernity, Indian Economic Social History Review, 40: 1.

2. Bachelard, G. (1994). The Poetics of Space, Boston, MA.

3. Betageri, A. (2018). The Breaking of Shakuntala: How a Bare Life is Transformed into Social Subject. Indian Institute of Technology Delhi.

4. Bhavani R. (2012). Document Raj: Writing and Scribes in Early Colonial South India, Chicago, IL and London.

5. Chawla, R. (2010). Raja Ravi Varma: Painter of Colonial India, Ahmedabad.

6. C. Raja Raja Varma's diaries (2005) have been published as Raja Ravi Varma: Portrait of an Artist (The Diary of C. Raja Raja Varma), eds Erwin Neumayer and Christine Schelberger, New Delhi.

7. Dinkar, N. (2014). Private Lives and Interior Spaces: Raja Ravi Varma's Scholar Paintings. Association of Art Historians.

8. Fried, M. (1980). Absorption and Theatricality: Painting and Beholder in the Age of Diderot, Berkeley, CA.
9. Kale, M.R. (1969). The Abhijnanashakuntalamof Kalidasa, Shri Jainendra Press, New Delhi.

10. Kaviraj,S. (2004). The invention of private life, in David Arnold and Stuart Blackburn, eds, Telling Lives in India: Biography, Autobiography and Life History, Bloomington and Indianapolis, IN.

11. Orsini, F. (2009). Print and Pleasure: Popular Literature and Entertaining Fictions in Colonial North India, Ranikhet.

12. Pattanaik, D. (2003). Indian Mythology. Inner Traditions Rochester, Vermont.

13. Ramen, F. (2008). Indian Mythology. The Rosen Publishing Group, Inc. NY

14. Report on the Census of Travancore, Travancore, 1876.

15. Thakurta, G.T. (1986). Westernisation and Tradition in South Indian Painting in the Nineteenth Century: The Case of Raja Ravi Varma (1848-1906). Sage Publications

16. Varma, C.R.R. (1896). A narrative of the tour in upper India of His Highness Prince Martanda Varma, of Travancore, Trivandrum.

17. Veniyoor, E. M. J. (1981). Raja Ravi Varma, Trivandrum.

How to cite this article: Adhikari A, Saha B. Shakuntala: as authored by Kalidas and painted by Raja Ravi Varma. Galore International Journal of Applied Sciences \& Humanities. 2021; 5(4): 45-53. DOI: https://doi.org/ 10.52403/gijash.20211008 